\title{
人間と協調作業をする分散ロボット ${ }^{\dagger}$
}

\section{畧見 達夫*}

\section{1. はじめに}

LIFE 知的ロボットプロジェクトでは、92 年 4 月から 95 年 3 月までの後半 3 年間、「人間と共生 する自律分散ロボットシステム」をテーマにかか げ、その基礎技術の確立と、コンピュータシミュ レーションおよびミニチュアの実機ロボットをも ちいた実証試験システムの作成を目標に研究を行 なった。自律移動ロボットの研究に直接携わった 経験のまったくない、ある意味で素人の研究チー ムが、最終的には、人間と自律分散移動ロボット の協調作業という他に例のないテーマに対して、 1つのプロトタイプを作り上げることができた。 研究成果については、FUZZ-IEEE/IFES'95の論 文[1〜5]を参照いただくことにして、ここでは、 3 年間を振り返り、その足跡について紹介しよう。

\section{2. テーマ決定までの道のり}

LIFE には前半の 3 年間にもロボットプロジェ クトがあり、実時間ファジィ制御システムの作成 ツールであるFRASH の開発と応用や、移動口ボ ット単体でのナビゲーションと視覚を用いた人の 認識を例題に、ファジィアルゴリズムやマクロ判 断の応用を試み、HERO-2000を用いた実機での

$†$ A Distributed Robot System That Makes Cooperative Works with Human

* Tatsuo UNEMI

創価大学工学部情報システム学科

Department of Information Systems Science, Soka University
実験を行なった。後半 3 年間のプロジェクトも、 当然ながら、その成果をふまえた卜で考え出され たものである。

しかし、実際のテーマ設定は、そうそんなり決 まったわけではなかった。まず、自律分散ロボッ トシステムを1つのキーワードにしようという方 向性は、前半のプロジェクトの最後、つまり 92 年 3 月に「来年度の研究計画」を作成した際に既に 決められていた。ロボットプロジェクトのメンバ 一も前半と後半でほぼ交代となり、プロジェクト 開始から 2 カ月ほどは、前半のプロジェクトが残 した計画書を前に研究計画を具体化すべく頭をか かえることになった。自律分散ロボットは、今も ホットな研究テーマである。これを掲げるのは結 構なことだとしても、どこにファジイ技術を生か すかが問題である。もう1つ前半のプロジェクト から引き継いだテーマは、未来の一般家庭で日常 的に使われるロボットを実現するための基礎技術 の確立という点であった。ファジィ技術を生かせ る「家庭で使う自律分散ロボットシステム」構築 のための基礎技術の模索、これが我々に課せられ た最初の課題であった。

その頃、多くの新人研究員は寺野所長のつぎの 言葉に頭を悩ませていた。すなわち「ファジィで もできるというのではだめだ。ファジィだからで きたというものを作って欲しい。」この指針自体は ファジィを名前に掲げる研究所としては当然のこ とではある。しかし、知能化技術の1つとしてし かファジィを捉えていなかった者にとって、これ はなかなかの難問であった。ファジィの本質につ 
いて考え、ファジィ以外の枠組みにはない部分が キーとなるような応用を考えなければならない。 ファジィ技術の本質はなにかという議論をここで 始めるには紙面が足りない。特にファジィを専門 とする方々には様々な意見があろうが、1つの見 方として、知的ロボットプロジェクトでは、人間 と機械の間を取り持つ道具としてファジィ技術を 考えることにした。単に自律分散ロボットの研究 というだけではファジィ「でも」できる程度のこ としかできまい。我々は「人間との共同作業」を タスクとして想定することにより、ファジィの特 徵を十分に生かせると考えた。

\section{3.人間とロボットの関係について考える}

人間と共同作業をするロボットと一口に言っても、 両者の関係としては様々な形態が考えられる。道 具としての機械という立場からは、ロボットは知 的であるよりも単純で分かりやすく、容易に制御 可能であるほうがよい。「知的」ロボットの研究と しては、分かりやすいが高機能であることが必要 である。

$$
\text { テーマのキーワードの } 1 \text { つは「共生」である。 }
$$
これが我々のプロジェクトで前提とされた人間と 機械の関係である。この考え方は、プロジェクト のアドバイザであった福田敏男先生の提案による ものだった。本来、異なる生物種間の生態学的関 係を表現するこの言葉を、生物ではないロボット との関係に持ち込むことは、いわゆるカテゴリー ミスマッチである。あえてこれを許すには「生き る」という言葉の意味を生物学的な意味からかな り拡張しなければならない。実際のところ、その 時点ではこのやっかいな問題は後で考えることに して、昨今の地球環境問題への社会的関心の高ま りと同時に時代のキーワードともなりつつある 「共生」を、とりあえずはプロジェクトのキーワ ードとして措借することにした。

具体的に研究を始めるに当たり、最も重要な要 素は例題として何を持ってくるかである。LIFE は特定の問題についての解決策を研究するところ
ではない。機械の知能化のための要素技術の $1 つ$ であるファジィ技術について、その基礎と応用分 野の拡大を図ろうというわけだから、例題の設定 自身が研究の対象でもあるわけだ。

もう一人のアドバイザであった廣田薫先生の案 でサッカーのようなチームプレーを必要とする対 戦ゲームも考えられたが、知的ロボットプロジェ クトに期待されるもう 1 つの重要な使命、すなわ ち、最終的な研究成果の総まとめとなる国際会議 IFES'95 で、一種のショウ的な要素のあるデモン ストレーションを実施したいということを考える と、観客が見て面白がるようなロボットサッカー を実現することは、ファジィとは別の部分でかな りの労力を必要とすると考えられることから、結 局、とりやめになった。

そこで、代替案として出てきたのが机と椅子の 並び変え作業である。机・椅子・ロボットの大き さや個数を適当に調整することで、問題の複雑さ を適当に変化させることができる。しかも、作業 の内容は誰にでも理解できる。机と椅子という 2 種類の対象物を想定した理由は、机は 2 人で運び、 椅子は 1 人で運ぶという仮定を設けることで、協 調が必要な作業と不要な作業を混在させるためで ある。期限付のプロジェクトで最終的な成果をき ちんとまとまった形で出そうとするなら、研究の 目標を、少なくとも達成すべきレベルと理想的な （欲張りな）レベルとの間に複数の目標レベルを段 階的に設定しておくのが妥当であろう。研究とい うものはいつまでにどこまでできるかなどという ことを事前に宣言することの難しい仕事である。 これまでにないものを作り出そうというのだから 当然ではあるが、かといって何ができるか分から ないというのでも困る。我々は、理想的なレベル として自律ロボット 4 台と人間が操縦するロボッ ト 1 台、合計 5 台のロボットで机を 5 台と椅子を 10 台の設定で、目標配置を協調的に達成すること を仮定した。これは理想的な目標である。実際、 研究を進めるに従って、我々は作業スペースの混 雑具合について甘く考えすぎていたことが、シミ ュレーションなどを通して徐々に明らかとなり、 
最終的にはそれぞれの数を削減せざるをえなくな つた。

机・椅子の並べ替え作業を人間とロボットが協 調的に行おうとするとき、ロボットは人間に対し てどのような態度で臨むのが理想的だろうか。自 然言語を用いた对話については知的インタフェー スプロジェクトが協調的な対話を行うコンサルテ ーションシステムについて研究を行った。对話と 共同作業との違いは、物理空間での非同期的な動 作を伴うか否かにある。また、我々が対象とした のは複数のロボットとの協調である。エージェン トの数が 2 の場合と 3 以上の場合とでは事情がか なり違う。2なら相手は一意に決まるが、3以上 になると対話の相手を決める手続きが必要になる。 あるいは、エージェントは必ずしも対話に参加す る必要がない。共同作業の場合には、あるエージ エントがまったく作業をやらなくても他のエージ エントによって全体のタスクは達成されるならば、 それでもよい。さらに、作業の遂行の最中にあま クおしゃべりが多いのは考えものである。作業の 効率と参加する人間の充実感を考えると、言葉で 情報をやり取りするよりも、互いに相手の動作か ら意四をくみ取れれば、コミュニケーションのた めの負荷をかなり軽減することができる。つまり、 「行動に基づく意図推論」である。

再び、共生について考えてみよう。これまで、 アシモフのロボット 3 原則を挙げるまでもなく、 ロボットは人間に奉仕すべき機械として考えられ てきた。人間の共生の相手としてロボットをとら えるということは、この枠組みを壊すことでもあ る。つまり、ロボットから人間への一方的な奉仕 ではなく、人間もロボットも互いに奉仕し合おう というわけである。ロボットに奉仕するとはどう いうことか。生物の場合、その個体あるいは遺伝 子を増やし種を維持することが唯一の目的である。 今のところロボットは自己増殖しない。ロボット の目的は、とりあえず、与えられたタスクを遂行 することであると考えることにしよう。共生の概 念を拡張し、互いに、他の目的を達成するために 協力し合うこととすれば、ロボットと人間の共生
も可能になる。ロボットは人間の奴隷ではなく、 对等な立場まで引き上げられる。つまり、ロボッ 卜は人間からの指令通りに動くのではなく、自身 の信念に従って行動する。そして、人間の指令を 受け入れない場合もあれば、必要と判断すれば人 間に指令を出すこともありうる。もちろん、共生 というからには、人間にとっても快適な相手であ る必要はある。つまり作業仲間としてのロボット である。

\section{4. 研究の分担と統合}

プロジェクト開始時点での研究員の数は、プロ ジェクトリーダを含め、4名であった。その後、 1 名が加わることになるが、とにかく、各々の研 究員が個々のテーマで論文を書けるぐらいの適当 なサブテーマを設定する必要があった。全体の研 究テーマを達成するための部分作業としての過不 足の無い分担と、それぞれの研究員が、それまで に大学あるいは出向元企業で行ってきた研究の背 景を生かすという、2つの点を考慮したテーマ設 定が必要である。

サブテーマとして、「行動からの意図推論」と「自 律移動ロボットによる協調作業」の研究は当然必 要である。前者は稲垣康弘研究員が担当し、後者 は腕ロボットのハードウェアについて経験のあつ た杉江弘研究員の担当とした。もう 1 つのテーマ として、これらをロボットシステムの上で実現し 統合するためのプログラミングと計算のアーキテ クチャの設計を揭げることにした。これは当プロ ジェクトで唯一ファジィに関わる研究の経験者で ある愛須英之研究員の研究テーマとなった。その 後加わった小野修一郎研究員には、今後重要にな ると思われるロボット学習を研究テーマとした。 もう 1つシステム全体を統合するための通信に関 する部分の実現についても経験を生かして小野研 究員の担当とした。プロジェクトの開始早々には、 ファジィプロトコルなるものをでっち上げ、あい まいな通信などというものが役に立つ可能性がな いか考えたこともあったが、結局、通信にあいま 
い性を導入することはとりやめた。通信の部分は 実証システム構築のための開発ということで、単 独の論文になるような研究テーマにはならなかっ た。

これらのサブテーマは本来は、全体のシステム として完全に統合されることが理想であったが、 残念ながら個々の研究員の仕事をそのまま統合す るという結果にはならなかった。1つには個々の 研究の完成と、それがシステムの一部として組み 込まれることの妥当性が必ずしも両立しないこと、 そして、統合のために必要とされる、全体の統一 的なアーキテクチャの設計が遅れたことに原因が ある。ロボット、パソコン、ワークステーション といった複数の異なるハードウェア上で動作する サブシステムを統合するには、特に通信プロトコ ルや、実時間でも動作を確実にする同期のための 機構もあわせて、初期の段階に設計しておかなけ ればならないが、特に後者についての設計が甘か ったことが最終的な統合までこぎつけなかったこ との原因であろう。通信については、ある種のブ ラックボードモデルを設計し、それを用いて部分 的には統合することができた。

結局、最終的なデモンストレーションでは、杉 江研究員のシステムをべースに、稲垣研究員がシ ミュレーションで実現した「行動からの意図推論」 のルールをプログラムに書き直して埋め込んだ。 動的なプランニングと制御のアーキテクチャ，お よび, 強化学習についてもハードウェアでの実験 を試みたが，全体システムの一部として埋め込む までには至らなかった。

\section{5. ハードウェアのこと}

幸いにしてハードウェア経験のある杉江研究員 と、アルバイト学生の橋本智己君という強力なコ ンビネーションによって、最終の IFES'95におけ るデモンストレーションを成功裏に終えることが できた。ロボットでなくともハードウェアの研究 には、それなりに手先の器用さが要求される。ど んなすばらしいアイディアも実機で動くかどうか
でかなり説得力が違ってくる。シミュレーション だけでは不十分であったり、シミュレーションが 困難な領域も多く存在する。ましてや、デモの効 果を考えるならば、コンピュータの画面に映るだ けよりは実機が動くほうが格段に説得力が違う。

LIFE の所内の $5 \mathrm{~m}$ 四方程度の実験室で $4 、 5$ 台 の移動ロボットを動き回らせるためには、ロボッ トのサイズがそれなりに小さくなければならない。 理想的には人間と対等に付き合えるような大きさ の人間程度のロボットが共生のプロトタイプとし て適切であろうが、残念ながらそれは実験環境の 制約から物理的に困難であった。もっとも、実験 室が十分広くても技術的にははるかに難しくなり そうなことは容易に予想がつく。我々は人間が直 接、作業に加わるのではなく、人間が操縦するリ モコンロボットを 1 台用意し、代役をやらせるこ とにした。

研究員の数から言って、所内ですべてを設計、 制作するほどの余裕もない。そこで、競技用のマ イクロマウスに目をつけた。大きさもちょうどい いし、市販品も何種類か存在する。競技会での優 勝実績のあるマシンが手ごろな值段で手に入った ので、センサやモデムの拡張をおこない、自律口 ボットと、人間の代役であるリモコンロボットを 作成した。16ビット CPU と左右両輪を独立に駆 動するスッテッピングモー夕、前後輸の向きを変 えるための DCサーボモータを備え、オプション でワイヤレスモデムもつく。これをまず 2 台購入。 試用の結果、十分我々の目的に合うと判断したの で予備もいれて合計 6 台を購入した。ロボット上 の CPUで全ての計算を行なうにはメモリと計算 速度の面で難があるのでワークステーション上で の推論結果をパソコンに接続したワイヤレスモデ ムを通して送信することで制御することにした。 ただし、一台はリモコンロボット、つまり、パソ ンコンに備え付けたジョイスティックの操作に従 って制御される人間の代役である。

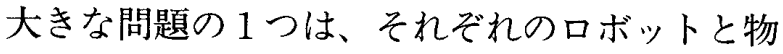
体の位置と姿勢を計測する方法である。理想的に は各々のロボットが独自の視覚を持ち、それぞれ 
にパターン認識を行なわせることで、相対的な位 置関係を把握する機能をもたせたい。しかし、こ のミニチュアロボットでそれを実現することは、 かなりの困難を伴うと考えらるため、我々は作業 スペースの天井にCCDカメラを備え付け、全体 の各物体の絶対位置と向きを得ることにした。た だし、カメラと画像処理装置から得られる $\pm 5 \mathrm{~cm}$ の精度と 0.5 秒間隔のサンプリングレートでは、 ロボットを十分な精度と速度で制御することはで きない。これには、ロボットに搭載した振動子ジ ヤイロとステッピングモータによるデッドレコニ ング、および、赤外線距離センサと夕ッチセンサ を併用することで対応した。

IFES'91のときのデモにともなう苦労話を聞い ていた我々は、稲垣研究員がその唯一の経験者だ ったが、IFES'95でも、数日の泊まり込みを覚悟し ていた。しかし実際やってみると、思ったよりす んなりと動作した。他のハードウェアのデモが隣 接していなかったことも多分好都合だったにちが いない。当初の目標よりは若干縮小されたものの、 2 台の自律移動ロボットと、1 台の人間が操縦す るロボットとの協調作業によって、3 台の机と 3 台の椅子を並び変える作業を実演することができ た。

\section{6. おわりに}

1つ残念なことは、これで、この研究自身には続 きがないことである。欲を言えば、まだまだやり 残した研究課題はたくさんある。プロジェクトは 解散してしまったが、どこかで、我々の研究成果 が末来の技術の参考になれば幸いである。

以下に、課題のいくつかを挙げておこう。

自律分散と称しながら、天井カメラというグロ 一バルな認識システムを使うことは、ある意味で 反則である。複数の自律移動ロボットの局所的相 対的なセンサ情報だけから協調作業に必要な外界 の情報を得ること自体が、重要かつ困難な研究課 題である。

我々はあえて言葉によるコミュニケーションを
排除した。実際に人間同士が共同作業を行なう場 合には、知識情報の交換だけではなく、掛け声の ような動作の同期や注意の喚起のために音声を用 いることがある。人間と共同作業をするロボット にもこのような音声による情報交換の機能は必須 であろうと考えられる。

最後に、知的な機械、人間と対等な機械を研究・ 設計・普及すること自身が人間の社会にとって価 值のあることなのかどうか。また、そのような機 械が社会的に受け入れられるものなかどうかとい う問題も残されている。新しい科学技術は、たえ ず多少の反対意見を残しながらも、発達、普及し てきたという歴史があるが、新技術導入の前に、 それによってもたらされる負の面についても十分 気を配る必要があることは言うまでもない。

\section{謝 辞}

この研究プロジェクトに様々な形で関わった全 ての方々に感謝致します。

\section{参 考 文 献}

[1]T. Unemi, Y. Inagaki, S. Ono, H. Aisu, H. Sugie: On the Relation between Human and Robots in the future-a perspective from Fuzzy Engineering and Artificial Life, Proc. of the Intnl. Joint Conf. of the Fourth Intnl. Conf. on Fuzzy Systems and the Second Intnl. Fuzzy Engineering Symposium, 1689-1694, 1995.

[2]Y. Inagaki, S. Ono, H. Aisu, H. Sugie, T. Unemi: Behavior-based Intention Inference for Intelligent Robots cooperating with Human, Proc. of the Intnl. Joint Conf. of the Fourth Intnl. Conf. on Fuzzy Systems and the Second Intnl. Fuzzy Engineering Symposium, 1695$1700,1995$.

[ 3 ]H. Aisu, Y. Inagaki, S. Ono, H. Sugie, T. Unemi: A Robust Planning and Control System Handling Fuzziness, Proc. of the Intnl. Joint Conf. of the Fourth Intnl. Conf. on Fuzzy Systems and the Second Intnl. Fuzzy Engineering Symposium, 1701-1704, 1995. 
[4]H. Sugie, Y. Inagaki, S. Ono, H. Aisu, T. Unemi: Cooperation among Multiple Mobile Robots Using Intention Inference, Proc. of the Intnl. Joint Conf. of the Fourth Intnl. Conf. on Fuzzy Systems and the Second Intnl. Fuzzy Engineering Symposium, 1707-1712, 1995.

[5]S. Ono, Y. Inagaki, H. Aisu, H. Sugie, T. Unemi: Fast and Feasible Reinforcement Learning Algorithm, Proc. of the Intnl. Joint Conf. of the Fourth Intnl. Conf. on Fuzzy Sys-

[問い合わせ先]

厂192 東京都八王子市丹木町 1-236 創価大学工学部 畧見 達夫 㱐 : 0426-91-9429

[FAX : 0426-91-9312

E-mail: unemi@iss.soka.ac.jp tems and the Second Intnl. Fuzzy Engineering Symposium, 1713-1718, 1995.

\section{著 者 紹介}

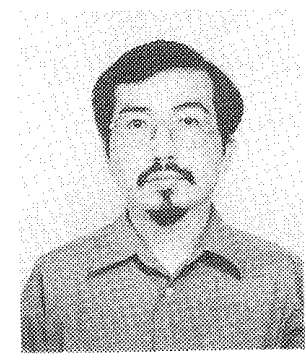

畧見 達夫 (うねみたつお)

創価大学工学部

1981年 東京工業大学大学院シス テム科学専攻博士課程を中退し同専 攻助手、1987年 長岡技術科学大学講 師、1992年 創価大学工学部講師、 1995年 同助教授現在に至る。1992年 4月から1995年3月まで国際ファジィ 工学研究所客員研究員。1994年博士 (工学)。人工知能学会、情報処理学 会、日本ファジィ学会等会員。 